\title{
SPECIAL REVIEW
}

\author{
Leonardo da Vinci Rediscovered. Carmen C. Bambach. \\ 4 vols. New Haven, CT: Yale University Press, 2019. xvi +502 pp. (vol. 1), \\ xiv +480 pp. (vol. 2), xiv + 634 pp. (vol. 3), xiv + 666 pp. (vol. 4). \$550.
}

For many of us, the appearance of a luxurious four-volume monograph from a university press is like a throwback to a previous era, when publishing in art history was less subject to profits and often generously subsidized. And Leonardo da Vinci Rediscovered might indeed be seen as a monumental conclusion to a golden age at Yale University Press, when the outstanding Gillian Malpass—who oversaw the production of these four volumes-was fine arts editor.

While being the single most popular monographic subject (dozens of volumes have appeared in the past year alone), Leonardo is hardly a typical one. The artist, for better or worse, is the engine of lucrative commercial publishing, in parallel with his everescalating trade value since the turn of the twenty-first century and the ubiquity of the "Da Vinci" mass cultural phenomenon. Bambach's compendious and authoritative work could ideally be seen as an antidote to the ugliness of an inflated art market, of sensationalist pseudoscience, and "Da Vinci" hoaxes. It will not stem the flow of nonsense, but it will provide a touchstone of mostly reliable information and judicious handling of material evidence and documentary sources. The author takes logical and confidently argued positions, mostly without overt polemics (at least in the main text).

Why "rediscovered"? A strange designation for an artist who in the past twenty years has been the subject of seven large-scale exhibitions at major institutions and about a dozen more focused ones. Bambach's point is to align her account with what she sees as the tangible gains of those exhibitions: the possibility of studying the artist's drawings, notebooks, and surviving paintings in tandem, together with the data made available through conservation of several of the paintings and through new imaging technologies. "Rediscovery" essentially means the reaffirmation and updating of empirical methods for the evaluation of Leonardo's legacy, typified by the nineteenth- and early twentiethcentury scholars Bambach cites (Charles Ravaisson-Mollien, Edmondo Solmi, Gerolamo Calvi, et al.). There is, correspondingly, less of an engagement with the more conceptual Leonardo(s) of the twentieth and twenty-first centuries- the Freudians, Leo Steinberg, Frank Fehrenbach, Michael W. Cole, Hans Ost, Daniel Arasse, Robert Zwijnenberg, David Summers, et al., who draw on history of science and medicine and on postformalist critical strategies in art history and the humanities. Bambach is explicit about her methodological distance from Romantic and postmodern notions of Leonardo's errancy, underachievement, and "creative chaos" (for example, Zwijnenberg, cited at 1:72) and from 
Martin Kemp's more idealist view of the fundamental unity of all of Leonardo's creative and scientific endeavors, perhaps the most influential paradigm for anyone teaching or writing about Leonardo over the past forty years.

Bambach describes her monograph as a "biographical-archaeological" study, the first three volumes respectively treating Leonardo's youth, maturity, and old age, the fourth with appendixes and the extensive notes, so readers can keep this open as they follow the main text. There are some gestures toward conventions of biographical writing, which perhaps underscore why most art historians avoid the form: appeals to a putative "temperament" that "never managed to fit within the practical traditions of art production and the socioeconomic structures of the Italian Renaissance" (1:4), or where the author feels called upon — in her account of Leonardo's Roman sojourn — “to recalibrate the context of this part of his career with equanimity and sensitivity to his vision and interior life" (3:309).

Yet it is soon apparent that Bambach has very little invested in biography as a principle of explanation. We are told that "Leonardo's homosexuality can hardly be questioned given his long-term friendships with men who never married" (1:89). The reader might wonder who these men are, since so many are referred to over the hundreds of pages of text: presumably not his most intimate associates, Salai and Giovanfrancesco Melzi, who both married within a few years of the artist's death. The topic of sexuality is scarcely broached again, and never in the analysis of the works.

Bambach's elusive subject came across to this reader as an author-persona constantly seeking to enunciate itself, repetitively and recursively over many years, conscious of its performative shifts of voice, its acts of personation and appropriation from others. The huge and labyrinthine heart of the book consists of Bambach's grappling with a Leonardo whose attempts at self-integration on paper only achieve further proliferation and dissolution. It is fundamental to this account that Leonardo aspired to be a published author from early in his career, and that this career can itself be thought of as a series of unfinished commissions and projected books. She rightly makes the case for Leonardo's importance in the production of knowledge in the vernacular and is invaluable on the topic of Leonardo's reading. Unlike previous monographs, Bambach writes, hers is the first that attempts "to reconstruct a general typology of his manuscripts" so as to grasp "his sense of process and sequence of ideas," and to "recuperate the immediacy of his creative acts" (1:72).

Emphasis falls throughout on the different formats and functions of notebooks, right down to a discussion of toggles and tie-hook closures. There are lucid discussions of the Madrid Codices and the Codex Atlanticus from the 1480s and 1490s, with their famous designs for mechanical devices (perhaps intended to form the basis of a "theory of machines"); the repeatedly redrafted notes for a treatise on painting, which thwarted the lonely devotion of his literary executor and heir Giovanfrancesco Melzi, only to finally appear in published form in 1651 through the efforts of Cassiano del Pozzo and Nicolas Poussin; a book on water, fluid mechanics, and geomorphology (now 
known as the Codex Leicester); and the famous albums of anatomical drawings preserved in the Royal Library at Windsor. We grasp clear distinctions between the Libro di Bottega and collaborative drawing in the workshop-libri di segreti, like Paris MS A, with their highly finished architectural studies—and more sketchy miscellanies. In the Paris MS (the so-called Cesare Borgia Notebook), we can observe Leonardo on the road in the Marches and the Romagna, sketching on the spot and making ethnographic observations as he goes. Technical writings like the Turin manuscript on the flight of birds or the Windsor anatomical drawing books are comprehensively described and explained, along with their posthumous histories.

Such lengthy excursuses put considerable pressure on the biographical organization of the text. As the book expands, accounts of chronologically related events can be separated by up to one hundred pages and need lengthy recapitulation when the narrative is resumed. There are echoes of the Tristram Shandy problem, "The more I write, the more I shall have to write," which might have been avoided through paginated crossreferencing in the main text. Readers proceeding from beginning to end experience a strong sense of déjà vu, as material quite thoroughly explained in earlier sections is lengthily summarized in later ones. For instance, the 2005 discovery of an annotation to a volume of Cicero's letters by Agostino Vespucci, which refers to the Mona Lisa and other works by Leonardo as unfinished in 1503, is introduced in volume 1 (336), explicated in 2 (252-53), summarized again forty pages later (290-91), and again in the following chapters $(2: 353,3: 11)$.

Some of the most compelling and controversial arguments address the earliest phase of Leonardo's career-his training in the studio of Verrocchio, followed by a phase of professional partnership with his teacher and an unsuccessful few years of independent practice before his departure for Milan in 1481. We follow Bambach's confident distinctions between an "electrifying" Credi/Verrocchio theme sheet in Edinburgh as opposed to the "constipated" disposition of designs on the leaves of a workshop sketchbook ascribed to another Verrocchio follower, Francesco di Simone Ferrucci; Carlo Pedretti's claim to find Leonardo's hand or handwriting in the latter are dismantled, in a page of dense text $(1: 151)$.

The extent of Leonardo's involvement in Verrocchio's sculptural projects is highly controversial; while Leonardo later received commissions for equestrian monuments in Milan, there is not a single extant work of sculpture that can be ascribed to him on documentary grounds, although claims for his authorship have been made for several pieces chiefly in private hands. Bambach endorses only one: the attribution to Leonardo by Wilhelm Valentiner in 1932 and Francesco Cagliotti in 2004 and 2019 of the Victoria and Albert Museum's Virgin with the Laughing Child, since they reveal a "similar pictorial intelligence" to the celebrated drapery studies on linen. However, while the Leonardesque character of the drapery and the face of the Virgin are persuasively argued, the child's hilarity has no counterpart among the solemn and strangely self-conscious infants of Leonardo's drawings and paintings: if this is Leonardo, it is Leonardo working 
in collaboration, which would be entirely in character with the collective modes of production of the Verrocchio workshop.

Attention to Leonardo's individual drawings is inevitably partial and selective. Bambach fleetingly refers to the "ethereal" nude life study for a Saint John on blue paper of 1482-83, now in Windsor. There is much to comment on here-the figure's blatant sensuality, its departure from the standard garzone study in its emotive address to the beholder, and the fact that (and this is entirely characteristic of the artist) Leonardo returned to it decades later, producing a half-length painted variation in his Louvre Saint John. Correggio also appears to have known the drawing, and to quote it in his Detroit Mystic Marriage of Saint Catherine of around 1510, while the Valencian Fernando Yánez borrows the figure in his Christ Presenting the Redeemed of Limbo to the Virgin of ca. 1520 (Prado). While rightly relating the study to the Verrocchio Madonna di Piazza commission for Pistoia, Bambach has far more to say about Lorenzo di Credi's tidy and meticulous study for the same figure, now in the Louvre (1:148-49). In contrast to the scant treatment of Leonardo's Windsor Saint John, the "crudely drawn" study of a woman bathing a child known as Il Bagnetto receives an entire page of text, about nine hundred words.

Other provocative reassessments follow from her confident and independent dating of the artist's graphic output. Thus, the famous red chalk drawing of a bearded elderly man in Turin is redated on technical grounds to $1500-02$, while also reinstated as a selfportrait of Leonardo (1:29, repeated 2:291), a once-popular identification doubted by many scholars in recent years. In part, this is based on its affective qualities: "its poignant psychological grandeur. This is a man physically burdened by the power of his inner vision and intellect, as is indicated by his gaze of absorption." The fact that Leonardo was only in his forties in 1500-02 is rationalized by different concepts of aging in premodern Italy. She argues that Raphael's understanding of the drawing as a portrait of Leonardo led to his use of it for the figure of Plato in The School of Athens, even though "Leonardo was essentially an Aristotelean" (1:33).

Leonardo's anatomical study of the human vascular and urino-genital systems in Windsor (2:207) is redated to 1488-92 on the basis of style and technique and the "somewhat ornate ductus" of the script. This matters because the drawing has long been seen as derivative of the woodcut illustration known as "Phlebotomy Man" from Johannes Ketham's Fasciculus Medicinae, printed in Venice in 1494 (the first printed book on medicine with illustrations): "It is more plausible to credit him with producing the innovative design, rather than a derivative one." Leonardo's drawing of the internal organs and the "spiritual parts" (brain and nerves) has been regarded at best as a slight improvement of Ketham, a crude predecessor to the watershed anatomical illustrations of Vesalius. The redating implies a reassessment of Leonardo's importance for an emerging scientific world view, which has often been downplayed by several authoritative commentators in the history of medicine. 
Bambach makes strong claims for Leonardo's practice of draftsmanship and its broader historical significance. Repeatedly in this account she circles back to the revolutionary nature of the artist's sketching technique, "storming with the pen," as Lomazzo would call it, as well as the astonishing demonstrative force of his technical designs and anatomical studies. Very momentous claims are made for Leonardo's componimento inculto, not only as directly influential on Giorgione and Correggio, butthrough them—as an anticipation of Pollock, Johns, Twombly, and Duchamp.

Correspondingly, the Florentine Renaissance is firmly reinscribed as the origin of modern art. Despite living far from his native city for most of his professional life, Leonardo's entire practice and mentality is characterized as "Florentine." I have some problems with this. While it is true that "the quest for sculptural values was a fundamental element of the Tuscan tradition of painting and the vocabulary of design" (1:84), that was also characteristic of centers like Padua after 1450. The later 1400s was an era of new experimental drawing practices across the peninsula, some of which developed in tandem with architecture and, in particular, with engraving. Mantegna and Bramante were interested in its possibilities, the disegno of the former particularly attuned to the medium. It remained a specialist medium in Florence, and the leading workshops for painting and sculpture manifest little interest in it. Bambach refers to Antonio Pollaiuolo's drawing of Hercules showing the "disciplined marks as a printmaker" (1:156), but the single print associated with Pollaiuolo probably dates from considerably later than the 1460s. Evidence of the print's clear impact on the work of other artists (as distinct from the impact of other Pollaiuolo models) is not found before the late 1480s (see my discussion in Andrea Mantegna: Humanist Aesthetics, Faith, and the Force of Images [2020]).

Bambach, a curator at the Metropolitan Museum, has a long acquaintance with Leonardo's unfinished panel of Saint Jerome, which she exhibited in New York in 2003-04 and again in 2019. Arguing for a date following Leonardo's move to Milan ca. 1481, she intriguingly suggests that Leonardo may have reworked the painting as late as 1510, around the time of his dissection of a centenarian. Her remarks are otherwise a little contradictory and have (appropriately for the painting in question) the character of a palimpsest of thoughts accumulating and shifting over many years of thinking about one work. She writes that the work is "Milanese in its method of construction and in its influential following by a younger generation of Milanese artists" (1:322), but then insists on the fundamental fiorentinità of the Saint Jerome, through comparisons with generically similar and far more conventional works by Verrocchio and Filippino Lippi (see 4:149n116). Bambach was formerly more willing to accept the resonance of the figure's anguished athleticism with North Italian treatments of the subject (see her Leonardo da Vinci, Master Draftsman [2003], 376). Far more compelling analogues are Marco Zoppo's depiction of the saint in the Collegio di Spagna predella of ca. 1460, or the Ferrarese Cosmè Tura's painting of ca. 1480 (National Gallery, London). 
What does it mean to insist on the fiorentinità of the Saint Jerome? What is to be gained by so doing? Might we not see works of art by traveling artists in terms of convergences and adaptations, as inventions without unitary provenances? Recent work on Leonardo's almost three decades in Milan has explored the importance of a cultural milieu very different to Florence; the traditional anglophone prejudice against a feudal princely court with a late Gothic and conservative artistic tradition has given way to an understanding of a cosmopolitan city defined by rich patterns of exchange with Italian and transalpine centers. Florence promoted an artistic monoculture of stylistically consistent products at home and abroad; Milan supported a diversity of styles and workshops from Lombardy and further afield, including Florence. The underappreciated Bernardino Zenale makes a convenient traditional foil for Leonardo, but Milan was also the city where the Florentine Filarete worked in an architectural idiom highly unlike anything in Florence, and where Bramante and his protégé Bramantino sounded out the legacy of Piero della Francesca. Like their followers Pedro Fernandez of Murcia or Gaudenzio Ferrari from Piemonte, they offer testimony to an awareness of Leonardo, but not to the inevitability of his influence. Leonardo's artistic circle is easily stereotyped in terms of epigones known as the Leonardeschi (Bambach illustrates a delightful rebus showing that this is a term they applied to themselves), but it included artists with very different approaches to a modern manner.

Bambach's account of Leonardo's Milan years is richly documented and illustrated, but it betrays some of the traditional prejudices against what she calls the "very conservative, guild dominated society and art market of Milan" (1:313). An otherwise masterful account of the Virgin of the Rocks in the context of Immaculate Conception iconography, and of the large, carved, wooden, polychrome ensembles of which the panel originally formed a part, speculates that "it is perhaps to be imagined that Leonardo himself felt profoundly unmotivated to attend to a picture by his hand that was destined for an elephantine decorative structure that was not to his taste" $(1: 346)$.

Might it not be more productive to see Leonardo's encounter with a decidedly nonFlorentine local tradition as an experience that provoked him to think in new critical ways about the comparison of painting and sculpture? Leonardo, in Milan in the 1490s, composed his famous polemic against the literalism of sculpture, for its inability to overcome through illusion its own material nature. Painting, grounded in optics, subsumes and surpasses what is possible in sculpture: it commands all the fleeting effects of luminosity, transparency, and reflection registered by the eye in a moment of experience. The works of the sculptor are merely what they appear to be, but "the major cause of wonder that arises in painting is the appearance of something detached from the wall or other flat surface, deceiving subtle judgements with this effect, as it is not separated from the surface of the wall" (Leonardo on Painting, ed. Martin Kemp [1989], 44).

Florence, throughout the book, exerts a normalizing center of gravity. Regarding the enigma of Leonardo's early adult career before his move to Milan, Bambach unfolds a 
lengthy hypothesis about the artist's undocumented attachment to the circle of Lorenzo "il Magnifico" de' Medici (1:197). True, one posthumous source-the so-called Anonimo Magliabecchiano (ca. 1540)—makes this connection, stating that Leonardo (like Michelangelo, according to Vasari) associated with young artists at the Medici gardens near San Marco. Vasari may not have known the Anonimo, but it seems unlikely that he would have been unaware of or sought to suppress Leonardo's early Medici connections. Of course, everything in Florence can ultimately be traced to the Medici and to Lorenzo, a networking effect reflected in the organization of archives, but it might be more interesting to speculate on the survival of an artist on the outer fringes of this network.

Quibbles aside, this is a staggeringly impressive piece of work. While not suited for reading from beginning to end, it is accessibly written and will be an essential resource to students of Leonardo of all levels. Teaching a course on Leonardo in fall 2019, the present author found the books to be an invaluable roadmap through the overgrown thicket of Leonardo bibliography; the students—some of them candid about their resistance to library-based research-enjoyed their hours spent with the volumes. Yet Leonardo studies is a volatile field, and our understanding of his life and thought is always shifting as numerous small discoveries are made. Leonardo's role in the Salvator Mundi, a work unavailable to scholars for years, is a question far from resolved, and receives rather dismissive treatment here, with a photoshopped image of the painting before conservation (pages with corrected captions are now posted on the Yale University Press website); there is no corresponding illustration of the heavily damaged Last Supper before its recent reconstruction and consolidation. Similarly, much of the valuable material presented here about Melzi-here rightly called the "unsung hero" in the story of Leonardo's legacy_-will need to be reassessed in the light of recent publication of his will and the revelation of important new biographical details. For those, one should turn to Rossana Sacchi, "Per la biografia (e la geografia) di Francesco Melzi" (ACME 2 [2017]: 145-61). doi:10.1017/rqx.2020.220 